\title{
WATER RESOURCES OF CAMAS PRAIRIE, SOUTH-CENTRAL IDAHO
}

By H.W. Young

\section{U.S. GEOLOGICAL SURVEY}

Water-Resources Investigations 78-82

Open-File Report

Prepared in cooperation with the

Idaho Department of Water Resources

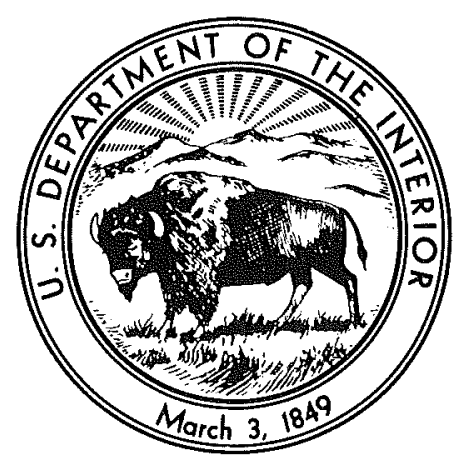




\section{UNITED STATES DEPARTMENT OF THE INTERIOR \\ CECIL D. ANDRUS, Secretary GEOLOGICAL SURVEY}

H. William Menard, Director

For additional information write to:

U.S. Geological Survey

Box 036, FBUSCH

550 West Fort Street

Boise, ID 83724 
This report is written in the "STOP" format. STOP (Sequential Thematic organization of Publications) is a writing format that presents a report in a series of independent, two-page units. The left page contains a brief, descriptive text; the right consists of graphic information that illustrates the text. The essence of the text is contained in the thematic heading and thesis statement, similar to a newsstory. The main body of the text contains supportive material and explanation. The accompanying table or illustration substantiates or supplements the text.

The STOP format permits quick review and helps the reader to understand the meaning of the section after reading only the thematic headings and thesis sentence. 
Conversion factors-

Acknowledgments--

1.0 INTRODUCTION

1.1 Purpose and scope-n- 3

1.2 Location and general features-_-n 4

1.3 U.S. Geological Survey numbering systems----- 6

2.0 HYDROLOGIC FRAMEWORK

2.1 Geologic and hydrologic setting-- 8

3.0 SURFACE WATER

3.1 Streamflow characteristics of Camas Creek---- 10

4.0 GROUND WATER

4.1 Occurrence-1- 12

4.2 Recharge-_-_-_-n-_-n 13

4.3 Movement--_- 16

4.4 Water-level fluctuations-_- 18

4.5 Discharge to streams---

4.6 Ground-water pumpage---_---_---------- 22

4.7 Effects of withdrawals-n-n 24

5.0 WATER QUALITY

5.1 Chemical character---- 1 - 26

5.2 Ground-water suitability for use---------- 29

6.0 DATA NEEDS

6.1 Suggestions for monitoring- 30

7.0 RESULTS

7.I Summary-- 32

8.0 SELECTED REFERENCES- 34 
The following conversion table is included for the convenience of those who prefer to use International system (SI) units rather than English units. Chemical data for concentrations are given in milligrams per liter (mg/L) or micrograms per liter $(\mu \mathrm{g} / \mathrm{L})$, which are (within the range of values presented) numericaliy equal to parts per million, or parts per billion, respectively.

Multiply English Units

inches (in)
feet (ft)
miles (mi)

acres

square miles $\left(m i^{2}\right)$

acre-feet (acre-ft)

gallons (gal)

gallons per minute (gal/min)

cubic feet per second $\left(\mathrm{ft}^{3} / \mathrm{s}\right)$
By

To Obtain SI Units

Iength

$\begin{array}{ll}25.40 & \text { millimeters }(\mathrm{mm}) \\ 0.3048 & \text { meters (m) } \\ 1.609 & \text { kilometers }(\mathrm{km})\end{array}$

Area

4047

2.590

square meters $\left(\mathrm{m}^{2}\right)$

square kilometers $\left(\mathrm{km}^{2}\right)$

Volume

1233 cubic meters $\left(\mathrm{m}^{3}\right)$

$3.785 \quad$ liters (L)

Flow

0.06309 liters per second $(\mathrm{L} / \mathrm{s})$

28.32 liters per second (L/s) 


\section{ACKNOWLEDGMENTS}

Many farmers and landowners in the Camas Prairie basin cooperated fully in this study by allowing access to their property, supplying information about their wells, and permitting water-level measurements to be made in their wells. Municipal officials and employees of the city of Fairfield supplied information about their water system. officials of Prairie Power Cooperative in Fairfield and Idaho Power Company in Gooding were helpful in offering data. To all the above, the author is grateful. 
1.0 TNTRODUCTION

1.1 Purpose and scope

\section{CAMAS PRAIRIE STUDY MADE TO DETERMINE EFFECTS OF GROUND-WATER PUMPING ON AVAILABILITY OF IRRIGATION WATER}

This study was designed to: (1) Determine present ground-water use, (2) document changes in water levels caused by pumping, and (3) refine estimate of recharge to the artesian aquifer.

The Camas Prairie basin has a rural population whose economy is dependent upon agriculture, which in turn, is dependent upon ground water for irrigation. The major source of irrigation water is an artesian (confined) aquifer that underlies the floor of the basin. Local residents and county and state water administrators are concerned that increased development of the artesian aquifer could cause declines in artesian pressure heads. Declines in the heads would reduce upward vertical recharge to a shallow watertable aquifer that overlies the artesian aquifer. The water-table aquifer, whose water level is generally less than $10 \mathrm{ft}$ below land surface, provides a type of subirrigation for the dry-farmed hay. Any significant reduction in recharge to this aquifer could affect production of nonirrigated crops. The objectives of this study were to determine the amount of present groundwater use, document changes in ground-water levels caused by pumping, and refine an earlier estimate (Walton, 1962) of annual ground-water recharge to the artesian aquifer.

Work accomplished during this 1-year study included an inventory of 287 wells and 1 spring; monthly water-level measurements in 21 wells; and collection of water samples for chemical analyses from 28 wells, 1 spring, and 7 streams. In addition, a pumpage inventory was made of all irrigation wells to determine irrigation withdrawals; seepage studies were made along Camas Creek and several tributaries to determine the relation between surface and ground waters; and monthly flow measurements were made at selected sites on 10 tributaries to Camas Creek to aid in evaluating annual recharge to the artesian system. Data collected as part of this study have been released by the U.S. Geological Survey in a companion report, "Selected Hydrologic Data, Camas Prairie, South-Central Idaho."

This study of the water resources of the Camas Prairie basin was made by the U.S. Geological Survey in cooperation with the Idaho Department of Water Resources. 
1.0 INTRODUCTION (Continued)

1.2 Location and general features

\section{CAMAS PRAIRIE IS AN INTERMONTANE BASIN OF 730 SQUARE MILES}

Camas Prairie is an intermontane basin located in south-central Idaho and is bounded on three sides by mountains. Its floor is a valley that averages about 5,000 ft in altitude above mean sea level and slopes gently eastward.

Camas Prairie basin occupies about $730 \mathrm{mi}^{2}$ of south-central Idaho and includes all of Camas county and parts of Elmore, Gooding, and Blaine Counties. Camas Prairie is an eastwardtrending intermontane basin that is bounded on three sides by mountains. Its floor is a valley that averages about $5,000 \mathrm{ft}$ in altitude above mean sea level and slopes gently eastward (map, opposite page). Flat-topped ridges separate the basin from the Snake River Plain. The Soldier Mountains form the northern boundary of the basin and rise to an altitude of 10,095 ft at Smoky Dome. The Mount Bennett Hills form the southern boundary and rise to 6,806 ft at Davis Mountain. The drainage divide to the west rises to about 6,200 ft and separates the basin from the South Fork of the Boise River.
Camas Creek drains the basin and is tributary to the Big Wood River. The creek flows generally eastward along the southern margin of valley-fill deposits in the center of the basin. Near Blaine, the creek has cut a canyon into basalt. Major tributaries to Camas Creek include Corral, Soldier, Elk, and Willow Creeks, which drain the southern slopes of the Soldier Mountains; and Dairy and McKinney Creeks, which drain the northern slopes of the Mount Bennett Hills. The climate of the basin is semiarid, with a mean annual precipitation ranging from about 15 in on the valley floor to slightly more than 25 in on the higher mountains. Mean annual temperature at Fairfield is about $5^{\circ} \mathrm{C}$ $\left(41^{\circ} \mathrm{F}\right)$. The growing season is short, having only about 60 freeze-free days. 
Approximate boundary of valley-fill deposits

_- _ Drainage-basin divide

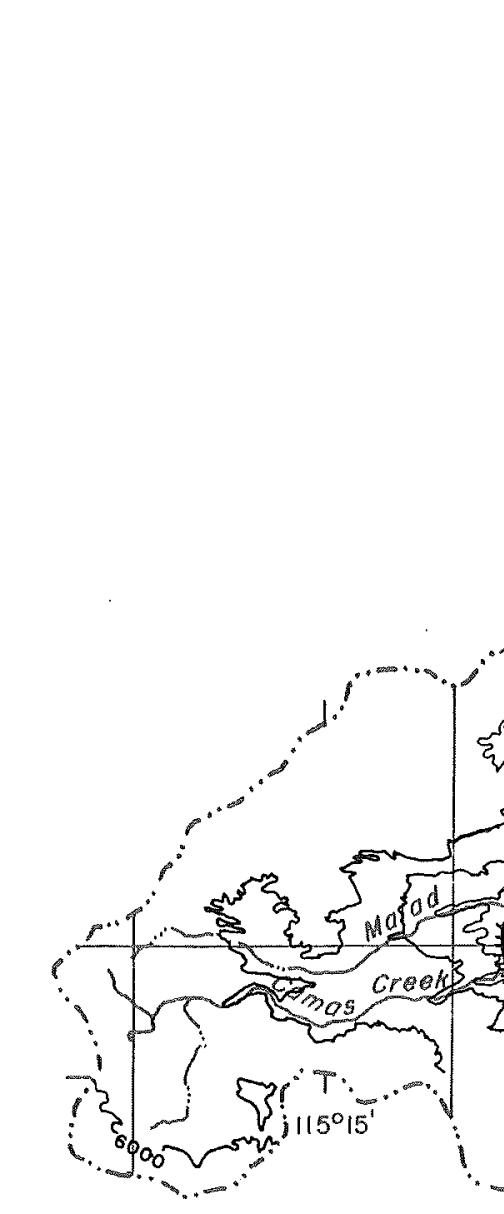

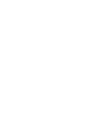


1.0 INTRODUCTION (Continued)

1.3 U.S. Geological Survey numbering system

\section{LOCATING DATA POINTS}

Wells and springs are located with reference to the Boise base line and meridian. Gaging stations are assigned numbers in downstream order.

The well- and springnumbering system used by the U.S. Geological Survey in Idaho indicates the location of wells or springs within the official rectangular subdivision of the public lands, with reference to the Boise base line and meridian. The first two segments of the number designate the township and range. The third segment gives the section number, followed by three letters and a numeral, which indicate the quarter section, the 40-acre tract, the 10-acre tract, and the serial number of the well within the tract, respectively. Quarter sections are lettered $A, B, C$, and $D$ in counterclockwise order from the northeast quarter of each section (see diagram opposite page). Within the quarter sections, 40-acre and 10-acre tracts are lettered in the same manner. Well 1S-12E13BAAl is in the $\mathrm{NE}_{4} \frac{1}{4} \mathrm{NE}_{\frac{1}{4}} \mathrm{NW}^{\frac{1}{4}}$ sec. 13, T. 1 S., R. 12 E., and was the first well inventoried in that tract. springs are designated by the letter "S" following the last numeral; for example, 1S-17E-34BAB1S.

Each gaging station and partial-record station has been assigned a number in downstream order in accordance with the permanent numbering system used by the U.S. Geological survey. Numbers are assigned in a downstream direction along the main stream, and stations on tributaries between main-stream stations are numbered in the order in which the tributaries enter the main stream. A similar order is followed on other ranks of tributaries. The complete 8-digit number, such as 13141500, which is used for the station Camas Creek near Blaine, includes the part number "13," indicating that Camas Creek is in the snake River basin, plus a 6-digit station number. 


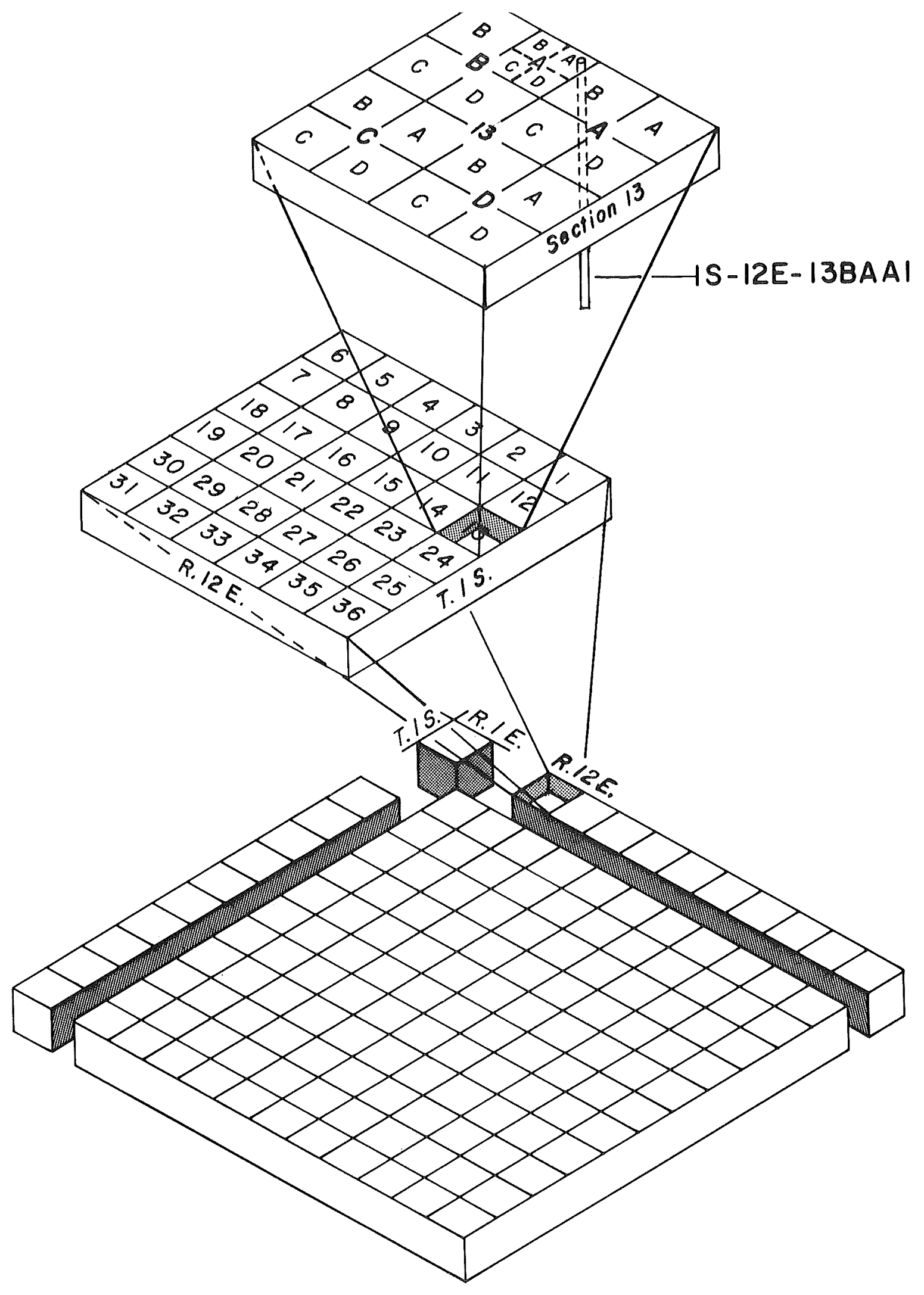

U,S, Geological SURVEY WELL- AND SPRING-NUMBERING SYSTEM 
2.0 HYDROLOGIC FRAMEWORK

2.1 Geologic and hydrologic setting

\section{VALLEY-FILL DEPOSITS AND BASALT YIELD GROUND WATER TO WELLS}

Principal aquifers are sand and gravel of the valley-fill deposits and basalt of the Bruneau Formation.

Rocks exposed in the Camas Prairie basin range in age from Carboniferous to Holocene and can be divided into two general groups-consolidated and unconsolidated. The consolidated rocks consist of sedimentary rocks and igneous rocks of intrusive and extrusive origin, which form the surrounding mountains and also underlie the valley floor. The unconsolidated rocks consist of valley-fill deposits comprising mostly stream and lake sediments. (The areal extent of the rock units is shown on the map, opposite page.)

The principal aquifers

in Camas Prairie are sand and gravel in the valley-fill deposits and basalt of the Bruneau Formation. (The approximate extent of the buried margin of the basalt is shown on the map, opposite page.) Yields from irrigation wells completed in the valley-fill deposits generally range from 400 to $1,200 \mathrm{gal} / \mathrm{min}$. Wells completed in the basalt generally have greater yields, with some wells producing more than 2,000 gal/min. The entire thickness of the valley fill has been penetrated by several wells. Most drillers' logs indicate that the depth to granite(?), which is thought to compose the basement rocks underlying the basin, is about 300 to $550 \mathrm{ft}$. However, the two deepest wells drilled in the basin--1S-13E-7DBD1, near Corral, reported depth $1,125 \mathrm{ft} ;$ and well $1 \mathrm{~S}-14 \mathrm{E}-$ 9DAAI, in Fairfield, reported depth 760 ft--did not penetrate granite, which suggests an irregular configuration of the granitic surface. 

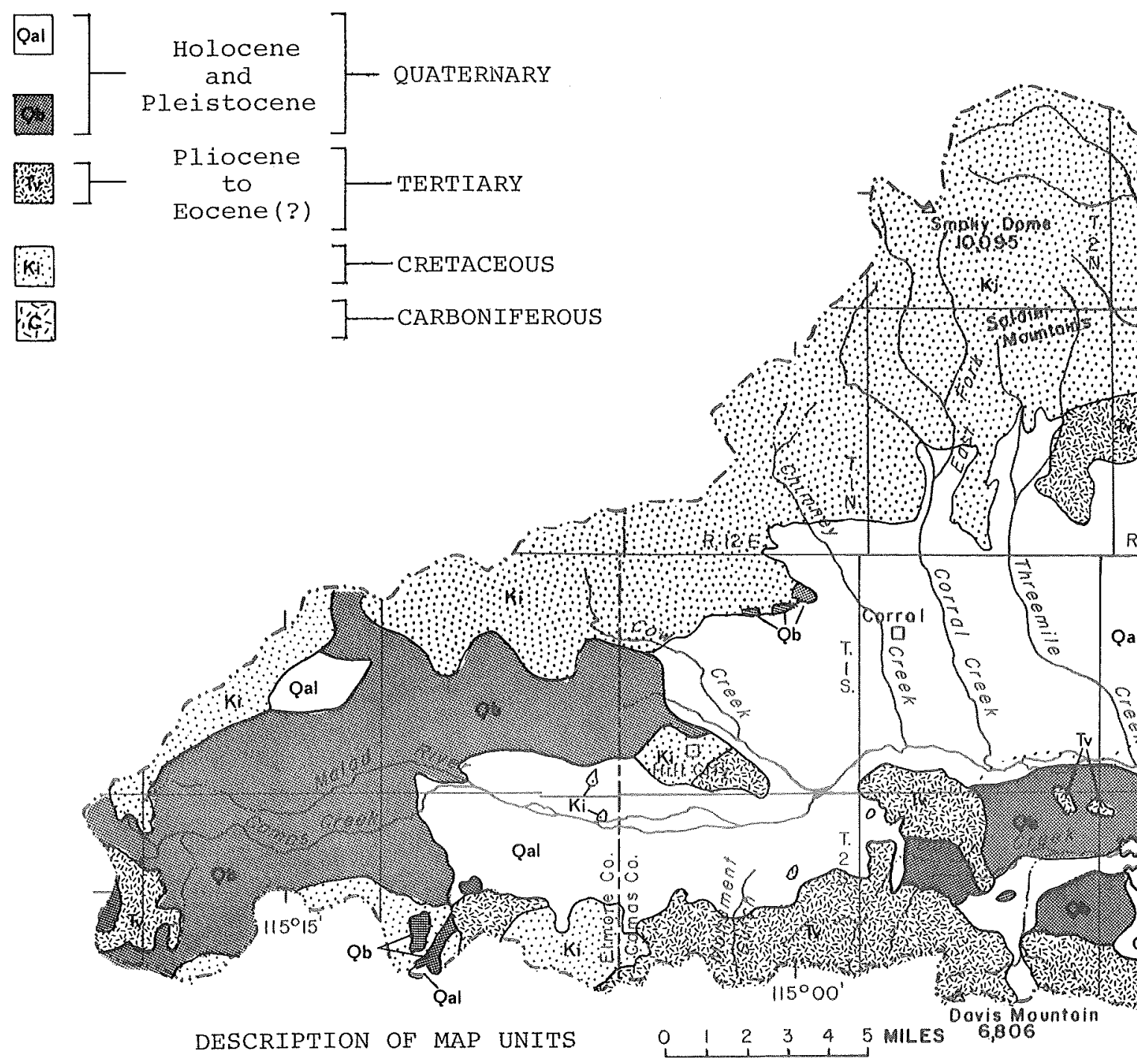

Qa1 VALLEY-FILI DEPOSITS - unconsolidated clay, silt, sand, and gravel

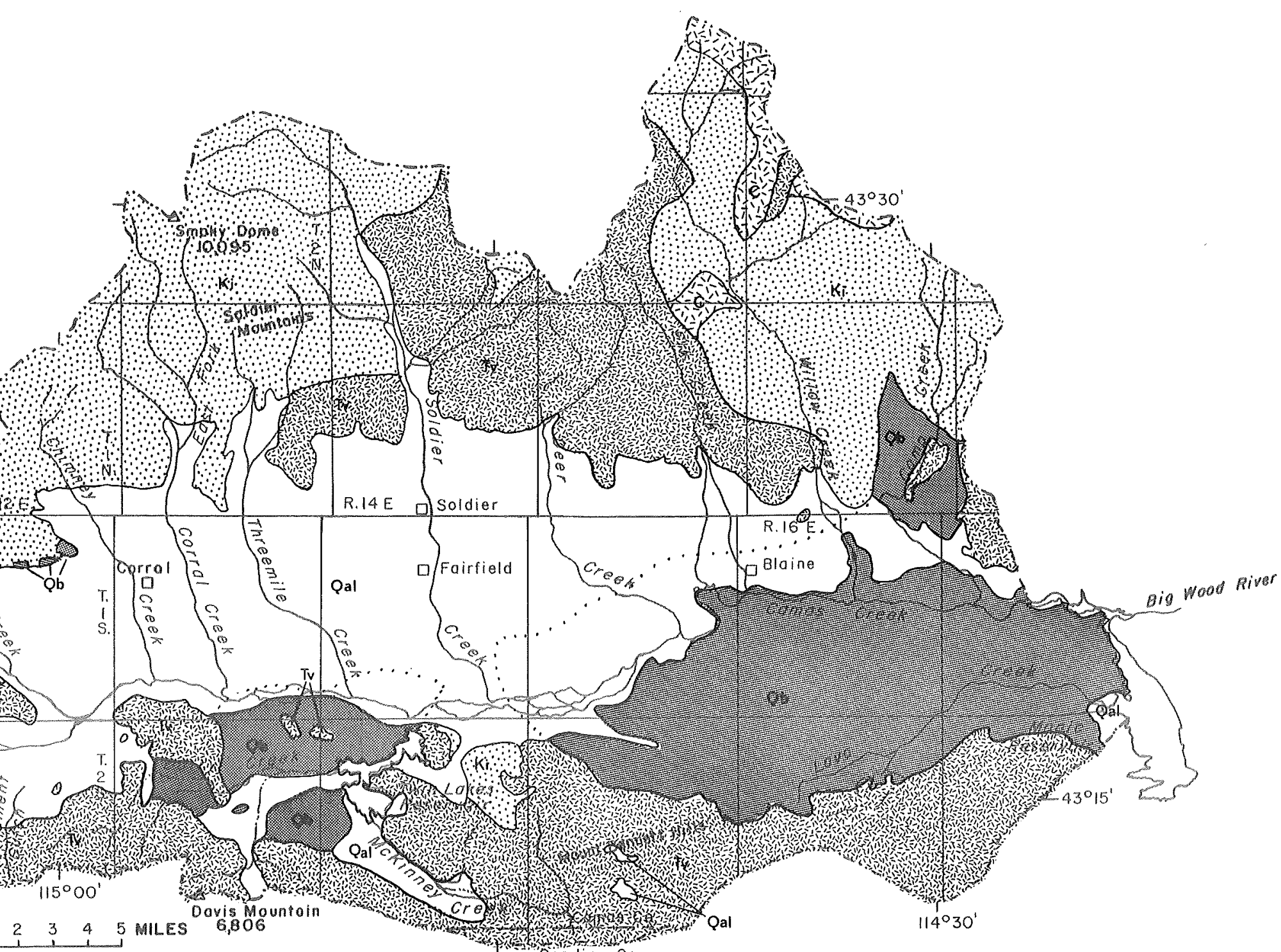

$14^{\circ} 45^{\text {cooding }}$ co.

Geology modified from Malde, Powers, and Marshall, 1963, and Ross and Forrester, 1947
1. BASALT OF THE BRUNEAU FORMATION - gray to black vesicular basalt

TERTIARY VOLCANIC ROCKS - tuffs and flows of variable lithology, ranging from rhyolite to andesite

IDAHO BATHOLITH - quartz monzonite and granodiorite

SEDIMENTARY ROCKS - chiefly calcareous Contact

.... Buried margin of basalt of the Bruneau Formation
GENERALIZED GEOLOGY AND BURIED MARGIN OF BASALT OF THE BRUNEAU FORMATION

-... Drainage-basin divide 
3.0 SURFACE WATER

3.1 Streamflow characteristics of Camas Creek

\title{
THE MEAN ANNUAL DISCHARGE OF CAMAS CREEK IS $191 \mathrm{FT}^{3} / \mathrm{s}$, HAVING A RANGE FROM 44 TO $437 \mathrm{FT}^{3} / \mathrm{s}$
}

\begin{abstract}
Discharge of Camas Creek in the 1977 water year was less than 7 percent of normal.
\end{abstract}

The daily discharge of

Camas Creek for the 1977

water year (October 1976 to

September 1977) ranged from a high in March of $39 \mathrm{ft} / \mathrm{s}$ to a low in August and september of $2.3 \mathrm{ft}^{3} / \mathrm{s}$, as shown by the streamflow hydrograph (opposite page). The mean discharge was $13 \mathrm{ft} 3 / \mathrm{s}(9,400$ acre-ft/yr). Monthly mean discharges ranged from a high in March of $31 \mathrm{ft}^{3} / \mathrm{s}$ to a low in August and September of $2.6 \mathrm{ft}^{3} / \mathrm{s}$. The discharge of Camas Creek in 1977 was less than 7 percent of the mean annual discharge. Continuous records of the discharge of Camas Creek have been collected since October 1944 at gaging station 13141500 (Camas Creek near Blaine). The gaging station, located in sec. 15, T. 1 S., R. 16 E., accounts for a drainage area of 648 $\mathrm{mi}^{2}$. Annual mean discharges for Camas Creek for the period 1945 to 1976 ranged from a high in 1952 of 437 $\mathrm{ft}^{3} / \mathrm{s}(316,000$ acre-ft/yr) to a low in 1961 of $44 \mathrm{ft}^{3} / \mathrm{s}$
$(32,000$ acre-ft/yr) and averaged $191 \mathrm{ft} 3 / \mathrm{s}(138,000$ acre-ft/yr). Mean monthly discharges for the same period ranged from a high in April of $1,065 \mathrm{ft}^{3} / \mathrm{s}$ to a low in september of 5.5 $\mathrm{ft}^{3} / \mathrm{s}$.

A flow-duration curve of the mean daily discharges of Camas Creek (opposite page) shows the percentage of time during which specified discharges were equaled or exceeded during a given period. As shown by the curve, a mean daily flow of about $25 \mathrm{ft}^{3} / \mathrm{s}$ was equaled or exceeded 50 percent of the time.

The curve showing magnitude and frequency of floods for Camas Creek shows that a peak discharge of about $7,400 \mathrm{ft}^{3} / \mathrm{s}$ may be expected to be equaled or exceeded once every 10 years; or, stated differently, there is a 10-percent chance that a peak discharge of this magnitude will occur in any given year. 

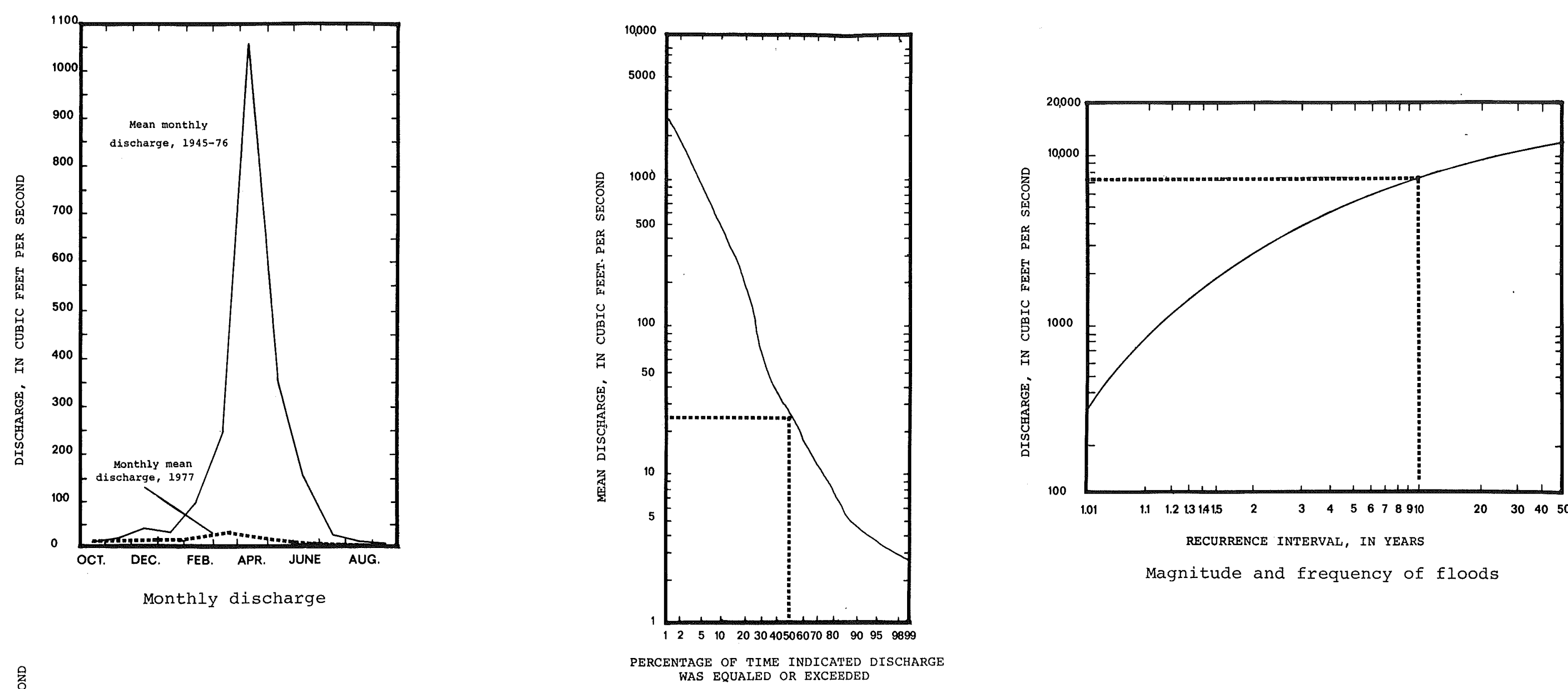

Duration curve of daily discharge

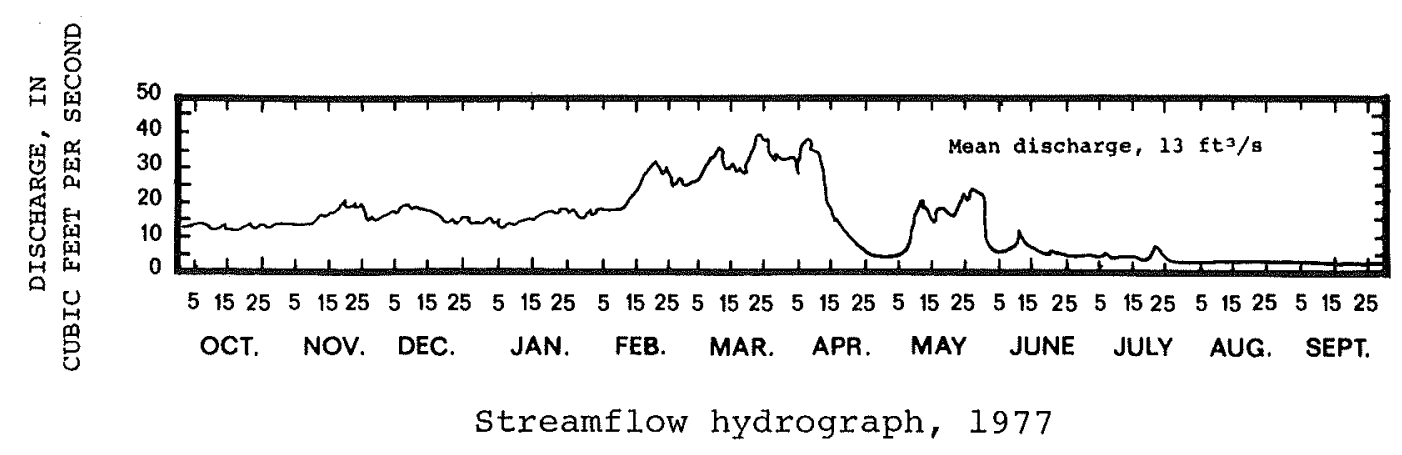

Annual mean discharge, 1945-76

Streamflow characteristics of Camas Creek near Blaine 
4.0 GROUND WATER

4.1 Occurrence

\section{GROUND WATER OCCURS UNDER ARTESIAN AND WATER-TABLE CONDITIONS}

Ground water is contained in intergranular spaces of the sand and gravel and in voids, fractures, and interflow zones in the basalt.

Ground water in the Camas Prairie basin is contained in intergranular spaces in the sand and gravel of the valley-fill deposits and in voids, fractures,. and interflow zones in the basalt of the Bruneau Formation.

The ground water occurs under artesian (confined) and water-table (unconfined) conditions in both rock units.

The occurrence of artesian water is the result of an extensive clay layer in the subsurface beneath the valley floor. The clay layer averages about $90 \mathrm{ft}$ in thickness and generally lies at a depth of about 100 to
200 ft below land surface. At places where the clay layer overlies buried basalt, artesian conditions prevail in the basalt. Water-table conditions prevail in the valley-fill deposits. The base of the unconfined aquifer generally is within 30 or $40 \mathrm{ft}$ of the land surface. Wells drilled in the valley-fill deposits below $40 \mathrm{ft}$, but above the major clay layer, may encounter some artesian pressure because of small, localized clay layers. water-table conditions in the basalt occur at places where the basalt is either at or near land surface. 
4.0 GROUND WATER (Continued)

4.2 Recharge

\section{CAMAS PRAIRIE AQUIFERS ARE RECHARGED BY PERCOLATION LOSSES FROM STREAMS AND BY PRECIPITATION}

Mean annual recharge to the artesian system is about 37,000 acre-ft; about 24,000 acre-ft from percolation losses from streams and about 13,000 acre-ft from precipitation on the recharge area.

All water in the basin is derived from precipitation falling within the drainage basin. The ground-water systems are recharged in several ways. The artesian aquifer is recharged by percolation losses from streams crossing the recharge area and precipitation on the recharge area. The recharge area is that part of the valley floor lying between the mountain fronts and the boundary on the valley floor where the potentiometric surface of the artesian aquifer is near or above land surface. The approximate boundary of flowing wells is shown on the map, opposite page. Mean annual recharge to the shallow water-table aquifer, which is primarily by upward vertical percolation from the underlying artesian aquifer, is abolit 20,000 acre-ft (Walton, 1962). Recharge also is derived from percolation losses from streams and precipitation on the valley floor.

The amount of water available from percolation losses for recharge to the artesian aquifer is dependent on surface runoff in streams from the surrounding mountains to the valley floor. To establish a basis of estimating annual surface-water runoff, a series of discharge measurements was made on 10 streams near the points where they begin to lose water to their alluvial fans. The measurements were made each month from March 1977 to February 1978. Using a method proposed by Riggs (1969), monthly mean flows for each stream were determined. Mean annual runoff for each stream was then estimated using a method described by Young and others (1977). The runoff map, shown on the opposite page, was constructed from the mean annual runoff data. Mean annual runoff from the mountains is about 120,000 acre-ft annually. Assuming that streams lose about 20 percent of their flow when crossing the recharge area, the estimated mean annual recharge to the artesian aquifer from percolation losses is 24,000 acre-ft. 


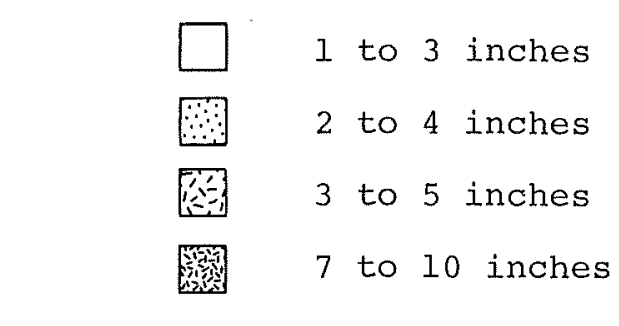

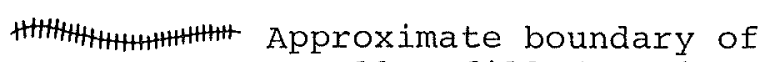
valley-fill deposits

TrmrrrrTाm Approximate boundary of flowing wells

Drainage-basin divide

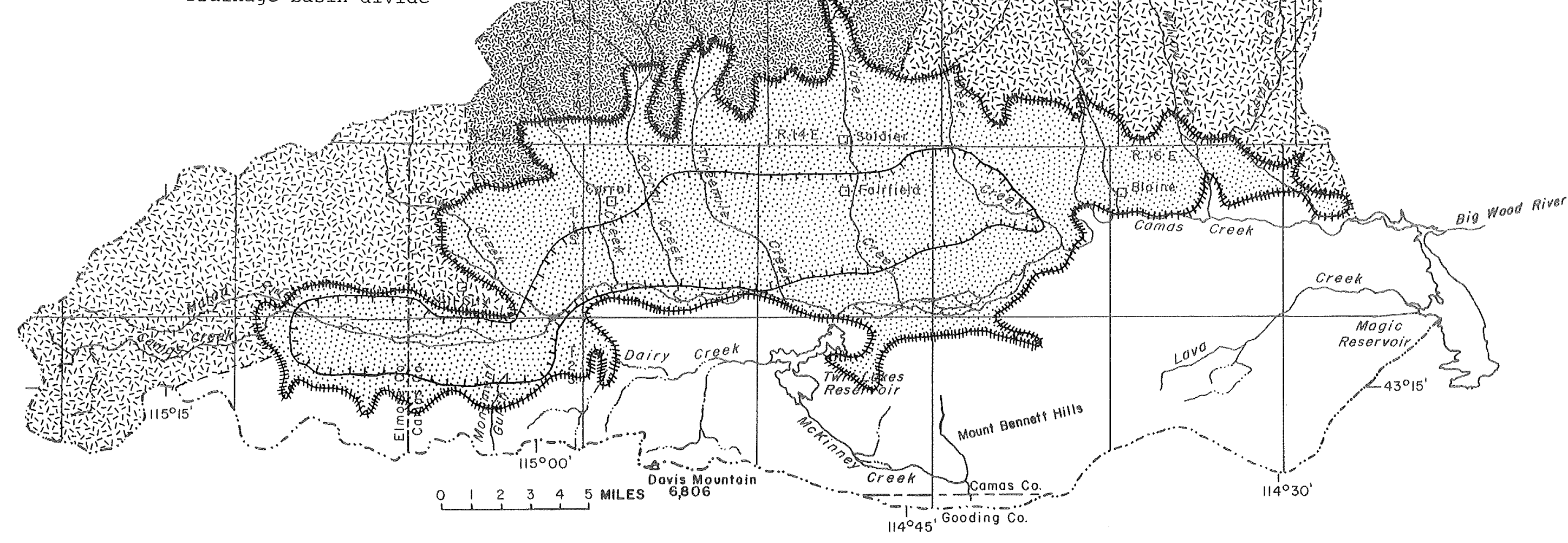

ESTIMATE OF MEAN ANNUAL RUNOFF AND BOUNDARY OF FLOWING WELLS 
Recharge to the artesian aquifer from precipitation falling directly on the recharge area was estimated by using a water budget, where ground-water recharge equals precipitation minus evapotranspiration minus runoff. Mean annual precipitation and evapotranspiration are 17 and 11 in, respectively (Walton, 1962). Mean annual runoff from the valley floor (shown on the map) is 4 in. Thus, 2 in of water is left to recharge the aquifer. Two inches of water over the recharge area, which covers approximately $120 \mathrm{mi}^{2}$, represents about 13,000 acre-ft. Therefore, total mean annual recharge to the artesian aquifer is about 37,000 acre-ft, which agrees favorably with a previous estimate (Walton, 1962) of 40,000 acre-ft. 
4.0 GROUND WATER (Continued)

4.3 Movement

\title{
GROUND WATER MOVES FROM AREAS OF RECHARGE TO AREAS OF DISCHARGE
}

\begin{abstract}
Ground water in the Camas Prairie basin generally moves toward Camas Creek, southeastward from the foot of the Soldier Mountains and northeastward from the foot of the Mount Bennett Hills.
\end{abstract}

The general direction of ground-water movement in the Camas Prairie basin can be inferred from the contours on the potentiometric surface shown on the map, opposite page. Ground-water movement is downgradient and at approximate right angles to the contours. The general direction of movement is shown by arrows. Ground water generally moves southeastward from the foot of the soldier
Mountains and northeastward from the foot of the Mount Bennett Hills toward Camas Creek. The shape of the potentiometric surface is based on measurements made in artesian wells in September 1977. The effects of heavy ground-water pumping are shown in several areas. The bending of the contours near, south, and southwest of Fairfield are a result of ground-water pumping. 
Potentiometric surface, September 1977-Dashed where approximately located. app is variable. Datum is mean sea level

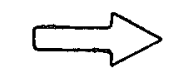

Generalized direction of ground-water movement

Drainage-basin divide

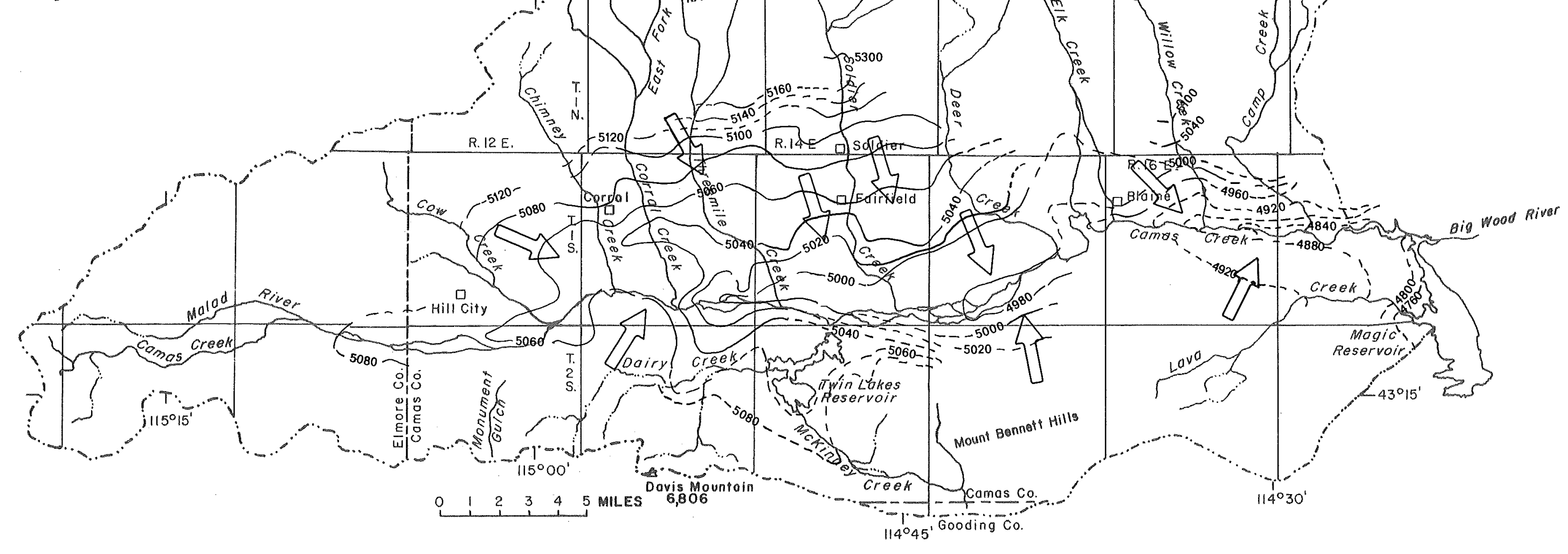

CONTOURS ON THE POTENTIOMETRIC SURFACE AND GENERALIZED
DIRECTION OF GROUND-WATER MOVEMENT, SEPTEMBER 1977 
4.0 GROUND WATER (Continued)

4.4 Water-Level Fluctuations

\section{PRESSURE HEADS SHOW DECLINE IN RESPONSE TO INCREASED PUMPING FOR IRRIGATION}

Since 1974, when a significant increase in pumping for irrigation began in Camas Prairie basin, pressure heads have declined 3 to $12 \mathrm{ft}$ in parts of the artesian aquifer. At one place, they drew down nearly $25 \mathrm{ft}$ in response to 1977 pumping.

Pressure heads have declined in wells $1 \mathrm{~S}-12 \mathrm{E}-$ 13BAA1, 1S-14E-8DDB1, and 1S15E-22AAAl (see hydrographs, opposite page) in areas of heavy pumping. The declines range from 3 to $12 \mathrm{ft}$ and began in about 1974. The greatest decline was in well 1S-14E-8DDBI. A11 three wells are completed in the artesian aquifer in Camas Prairie basin. Generally, the annual decline has increased each year since 1974 . A drawdown of nearly 25 ft was observed during the 1977 irrigation season in well IS-14E-24DADI. Well IS14E-7DDD1, completed in the shallow water-table aquifer, was dry at a depth of $10 \mathrm{ft}$ in July. This well is near an area of pumping for irrigation. The effects of the pumping on the artesian aquifer are shown by well 1S-14E-8DDB1, which dropped to nearly 9 ft below land surface during the 1977 irrigation season. The decline in artesian head, which would result in a reduction in upward vertical recharge to the water-table aquifer, may have partly contributed to the decline of the water table, as shown in well 1S-14E-7DDDl. The water level in well 1S-14E7DDD1 recovered to about 9 ft below land surface in February 1978, and the artesian head in well 1s$14 \mathrm{E}-8 \mathrm{DDB} 1$ rose to about $4 \mathrm{ft}$ above land surface. 

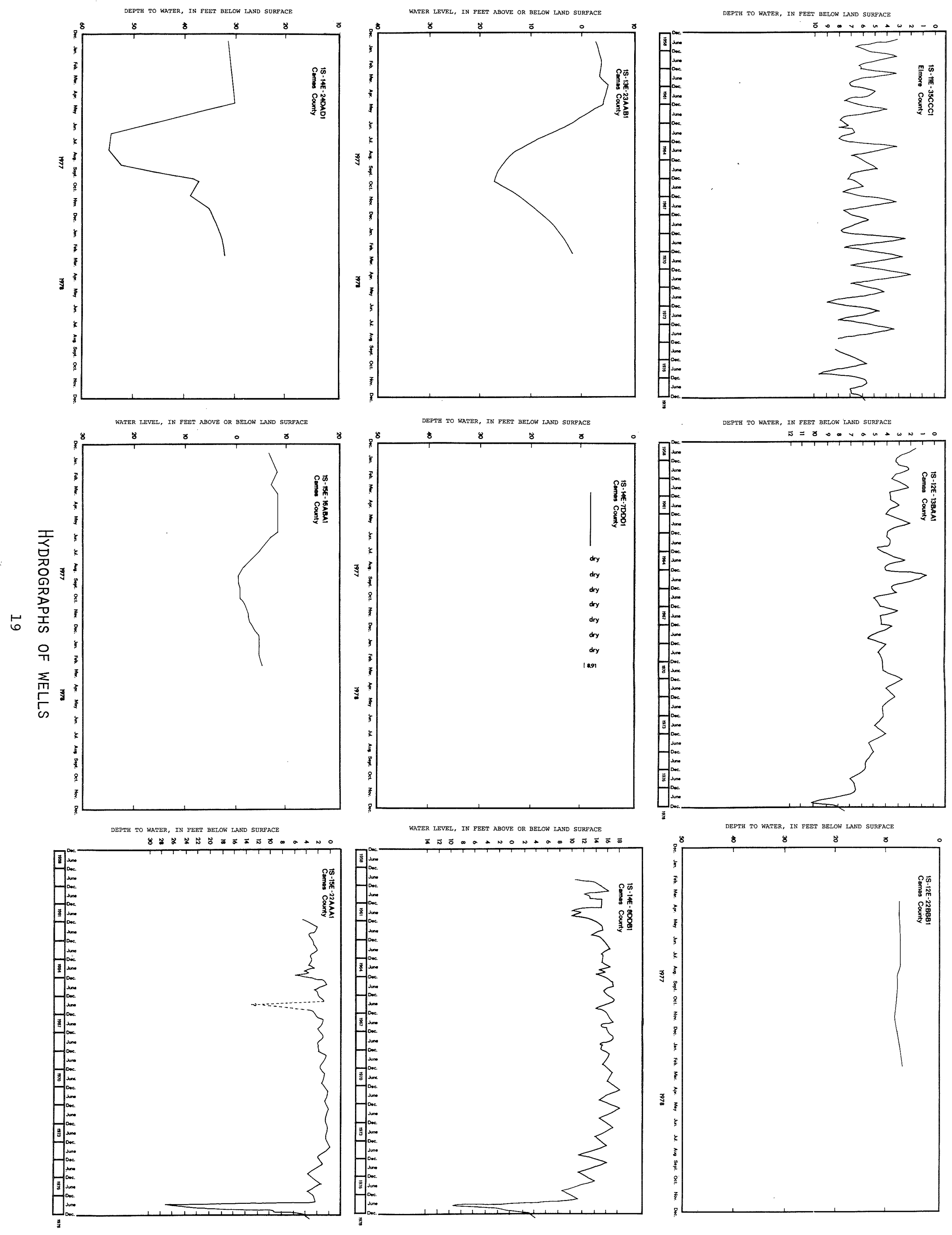
4.0 GROUND WATER (Continued)

4.5 Discharge to Streams

\section{GROUND WATER MAINTAINS STREAMFLOW}

Ground-water discharge from the basalt aquifer in the eastern part of Camas Prairie maintains streamflow in Camas, Willow, and Camp Creeks. Annual ground-water discharge to these streams is about 7,500 acre-ft.

\author{
Ground-water discharge \\ to Camas, Willow, and Camp \\ Creeks in the eastern part of \\ Camas Prairie at the time of \\ a seepage study made May 16- \\ 20, 1977, during a base-flow \\ period, was slightly more \\ than $10 \mathrm{ft}^{3} / \mathrm{s}$. Assuming that \\ ground-water discharge is \\ fairly constant, total ground \\ water discharged annually \\ from the basalt aquifer to \\ streamflow is about 7,500 \\ acre-ft. \\ A series of discharge \\ measurements, including all \\ inflows and outflows, along \\ Camas Creek and four selected \\ tributaries indicate that, \\ generally, streams in Camas \\ Prairie lose to the valley- \\ fill aquifer and gain from \\ the basalt aquifer. Dis- \\ charge measurements along \\ Camas Creek between sites 1 \\ and 11 (see opposite page)
}

generally show a small loss to the water-table aquifer in the valley-fill deposits. However, between sites 11 and 14, Camas Creek cuts deeply into basalt and drains the basalt aquifer. Ground-water discharge into

Camas Creek between sites 13 and 14 is about $5 \mathrm{ft}^{3} / \mathrm{s}$, which is slightly more than 20 percent of the total flow at site 14 . Corral, soldier, and Deer Creeks lose to the valley-fill aquifer. Willow Creek between sites $W-1$ and W-2 loses to the valley-fill aquifer. However, between sites $W-2$ and $W-5$, Willow Creek, like Camas Creek, cuts deeply into basalt and drains the basalt aquifer. Total ground-water discharge to Willow Creek is about 3 $\mathrm{ft}^{3} / \mathrm{s}$. 
$\Delta_{1}$ Station location and number

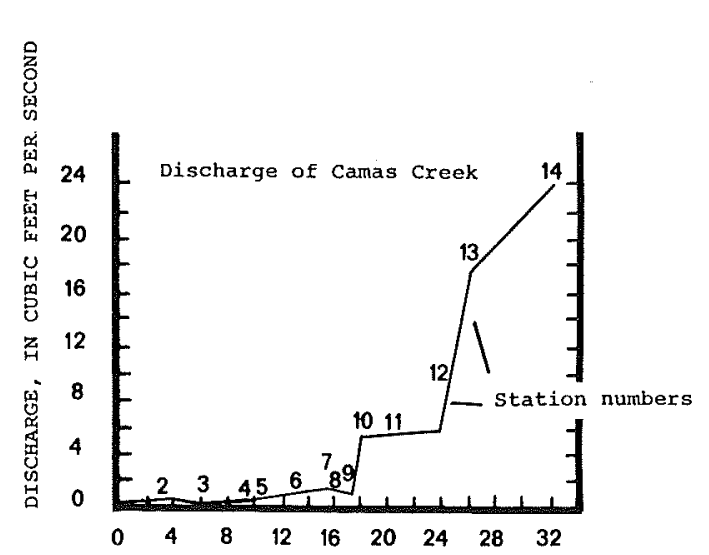

-.. Drainage-basin divide

DISTANCE DOWNSTREAM FROM
STATION 1, IN MIES
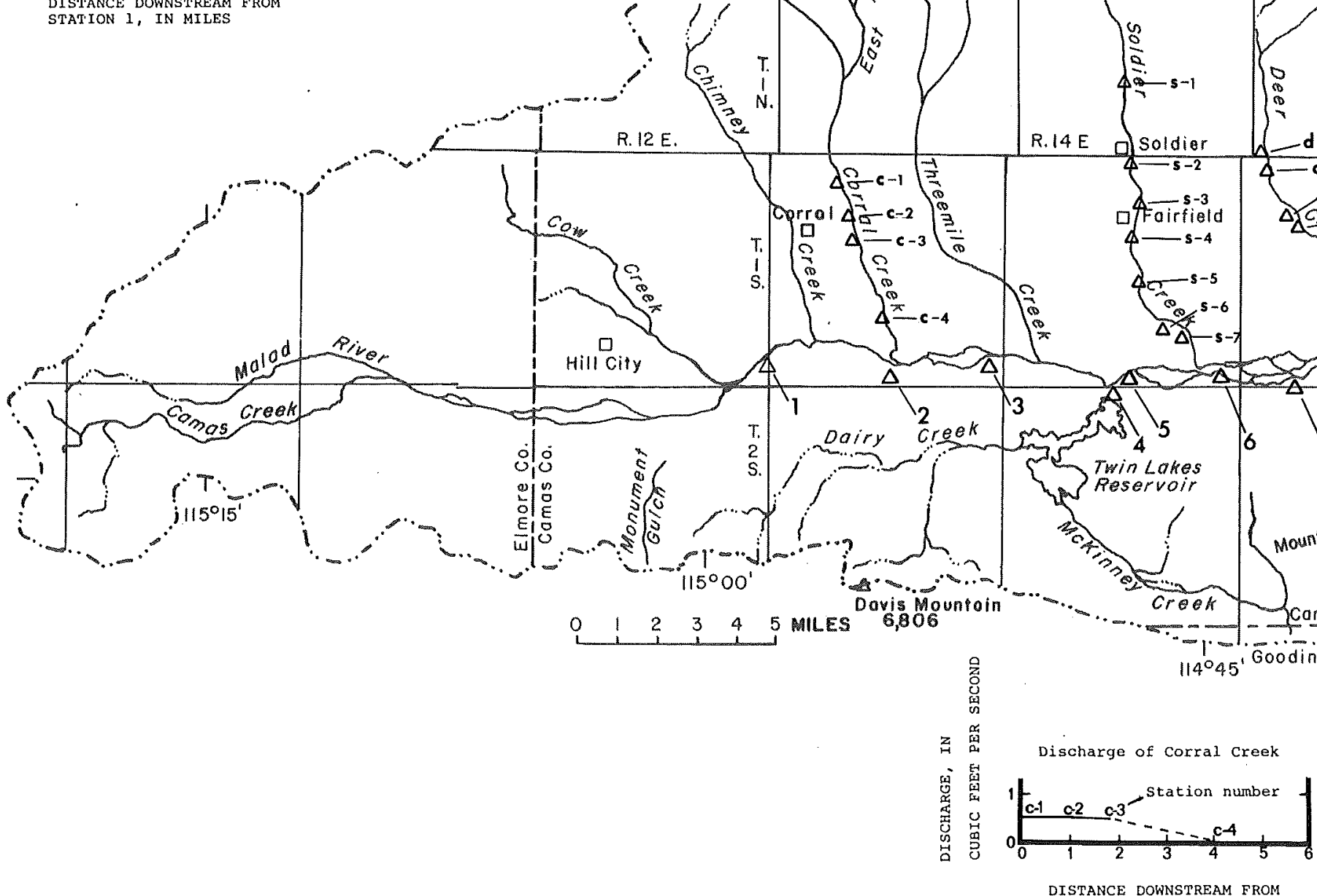

DISTANCE DOWNSTREAM FROM
STATION C-1, IN MILES

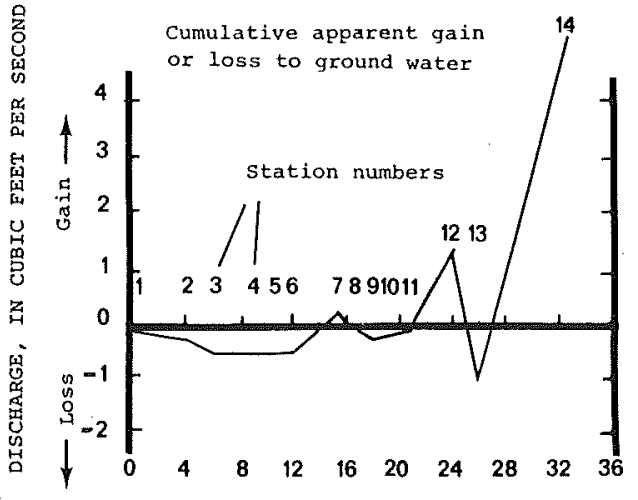

DISTANCE DDWNSTREAM FROM
STAIION 1, IN MILES
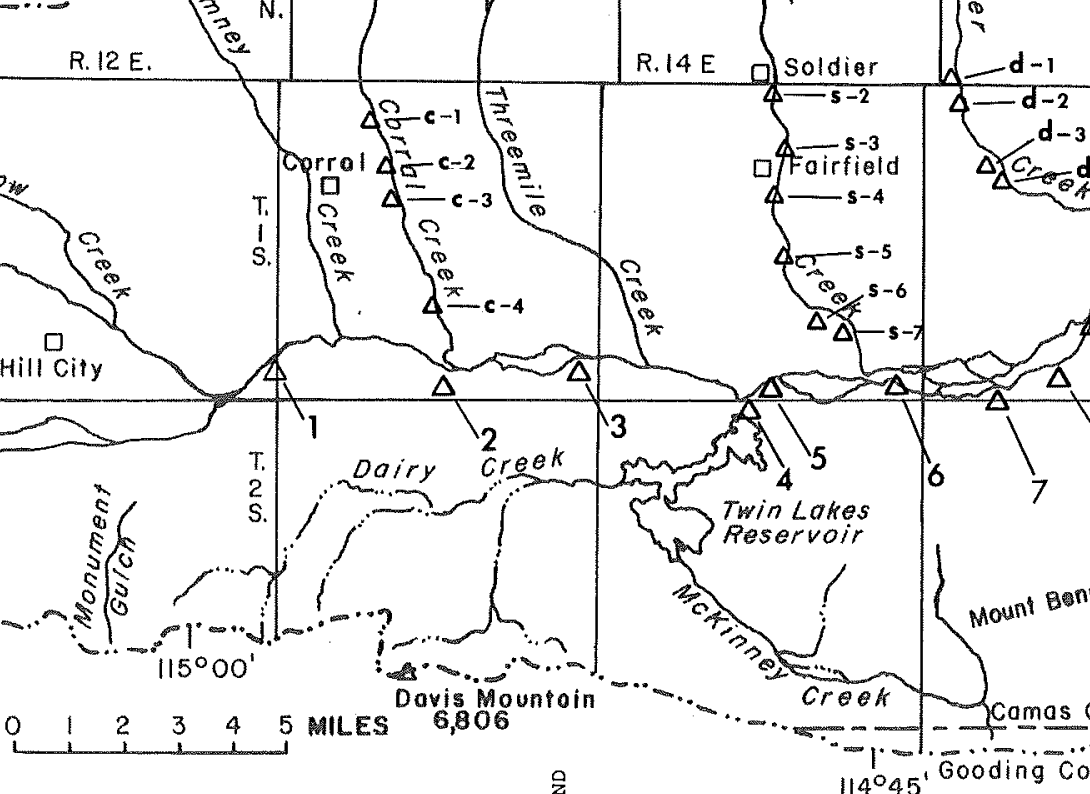

Results of seepage study, May 16 to May 20, 1977 
4.0 GROUND WATER (Continued)

4.6 Ground-Water Pumpage

\title{
GROUND-WATER USE INCREASES
}

\begin{abstract}
Ground-water withdrawals for irrigation and municipal use totaled nearly 9,500 acre-ft in 1977, compared to 1,350 acre-ft in 1957.
\end{abstract}

Twenty-nine irrigation wells and two municipal wells were pumped in the Camas Prairie basin in 1977. Irrigation pumpage in 1977 was 9,390 acre-ft, and municipal pumpage was 100 acreft, totaling nearly 9,500 acre-ft. Ground-water pumpage in 1957 for irrigation and municipal use was 1,350 acre-ft (Walton, 1962). Irrigation pumpage was determined by several methods. Eleven wells were equipped with totalizing flow meters, which were read at the beginning and end of the irrigation season. The pumps in two wells were powered by internal combustion engines, and total pumpage was calculated using the measured rate of discharge times the length of time pumped, which was reported by the well owners. Pumpage was calculated for 16 of the irrigation wells with aid of records obtained from power companies. For eight of these wells, pumpage was calculated using discharge measurements times number of pumping hours, derived from the power records. For the other eight wells, where discharge measurements could not be made, pumpage was calculated using the formula:

$$
Q=\frac{K w H}{1.8} \times(H+P)
$$

(Moreland, 1977). Average power consumed to lift 1 acre-ft of water 1 ft in the area is approximately 1.8 killowatthours. By measuring the pumping level of the well and either measuring or estimating the pressure head at the well, the total lift for each well was determined. Pumpage was then calculated using total lift and power consumed. Municipal pumpage for the city of Fairfield was determined assuming a percapita use of $230 \mathrm{gal} / \mathrm{d}$ (gallons per day) per person and a population of 401 . 


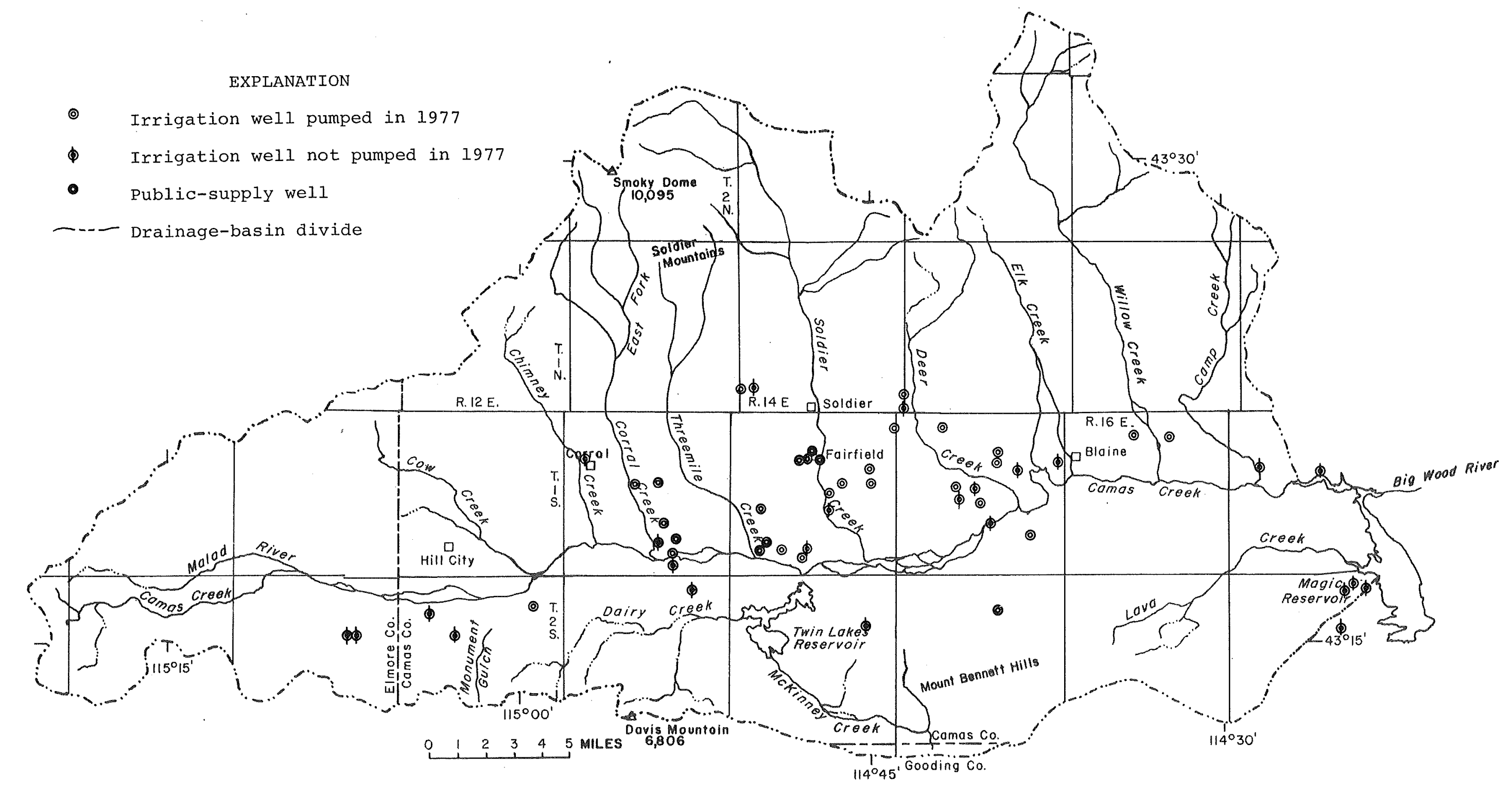

LOCATIONS OF IRRIGATION AND PUBLIC-SUPPLY WELLS 
4.0 GROUND WATER (Continued)

4.7 Effects of Witharawals

\section{POTENTIOMETRIC SURFACE DECLINES}

A comparison of water-level measurements made in september 1957 and september 1977 shows that potentiometric (pressure) levels in the artesian aquifer have declined more than 30 ft in places.

The effects of witharawals from the artesian aquifer in Camas Prairie basin are shown on the waterlevel change map, opposite page. The map was made by comparing water-level measurements made in september 1957 with those made in September 1977. Most de-

\author{
clines were in areas of \\ pumping for irrigation. \\ The largest declines, more \\ than $30 \mathrm{ft}$, were observed in \\ the sand and gravel part of \\ the artesian system. Smaller \\ declines, generally 5 to \\ $10 \mathrm{ft}$, were observed in the \\ basalt part of the artesian \\ system.
}




\section{EXPLANATION}

$-10-1$ LINE OF EQUAL CHANGE IN WATER LEVEL,
IN FEET--Dashed where approximately

located

- Drainage-basin divide

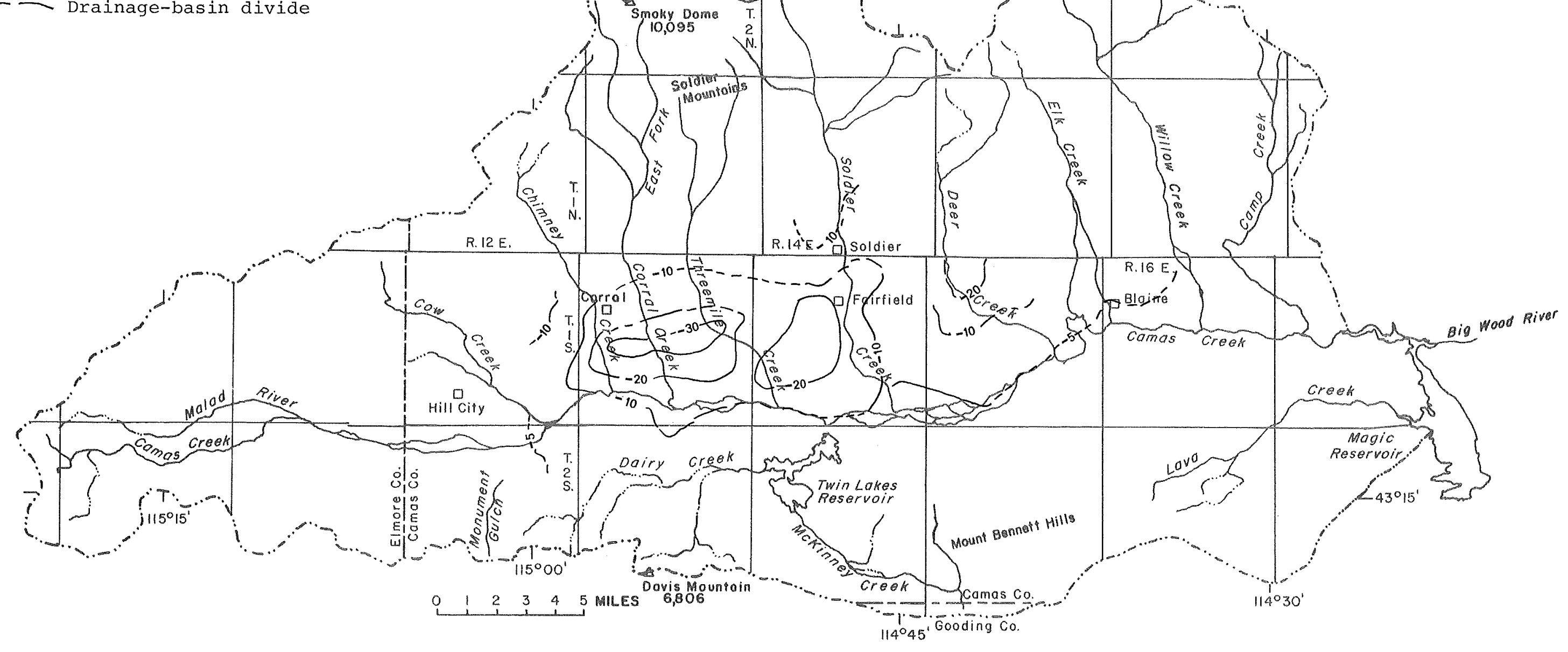

DeCLINES In THE POTENTIOMETRIC SURFACE, SePtember 1957 TO SEPTEMBER 1977 
5.0 WATER QUALITY

5.1 Chemical Character

\title{
WATER IS TYPICALLY A SODIUM OR CALCIUM BICARBONATE TYPE HAVING LOW DISSOLVED-SOLIDS CONCENTRATIONS
}

\begin{abstract}
The chemical character of ground water changes from a calcium bicarbonate to a sodium bicarbonate type as the water moves from a recharge to a discharge area. Most stream water is of the calcium bicarbonate type. Dissolved-solids concentrations are low and range from 61 to $284 \mathrm{mg} / \mathrm{L}$.
\end{abstract}

Ground water in the Camas Prairie basin is either a sodium or calcium bicarbonate type, as shown by pattern diagrams (Stiff, 1951) (opposite page). Ground water in the artesian aquifer is of the calcium bicarbonate type near and in the recharge area and tends toward a sodium bicarbonate type as it moves downgradient to discharge areas in the stream valley. Surface water in the basin is of the calcium bicarbonate type, except in Elk Creek and Monument Gulch, where it is of the sodium bicarbonate type. Ground water in the artesian aquifer shows an orderly increase in dissolved-solids concentrations as it moves through the system. This increase is apparent (opposite page) in samples from wells 1S-13E6DAAl, 1S-13E-12CCC1, 1S-14E19DAA1, and 1S-14E-33BADI. The dissolved-solids concentrations increased from 124 to $232 \mathrm{mg} / \mathrm{L}$. Water in the water-table aquifer is generally a calcium bicarbonate type, and dissolvedsolids concentrations in sampled waters (wells 1s13E-17CBB2, 1S-15E-19BCB1, and 1S-16E-18BAB1) range from 129 to $279 \mathrm{mg} / \mathrm{L}$. The dissolved-solids concentrations in surface water range from 61 to 147 $\mathrm{mg} / \mathrm{L}$, and, with the exceptions of Elk Creek and Monument Gulch, the water is of the calcium bicarbonate type. Sodium bicarbonate type water in Elk Creek results from hot water entering the creek from Elk Creek Hot Springs. The chemical character of Monument Gulch is also influenced by spring discharge. Sodium bicarbonate type water in the artesian aquifer may partly result from thermal waters entering the artesian system. Known thermal water in the area (Young and Mitchell, 1973) is characteristically of a sodium bicarbonate type. The dissolved-solids concentrations in the pat- 
EXPLANATION

Pattern diagram

232. dissolved solids, in milligrams per liter

CATIONS (+) AHIONS (-)

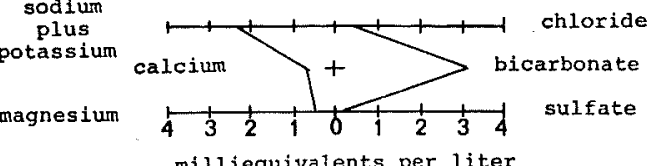

Surface-water sample stippled Water-table sample hatchured

Surface-water site

- 33BAB1

We11 and number

34BABIS

Spring and number

- $\cdots+\cdots$

Drainage-basin divide

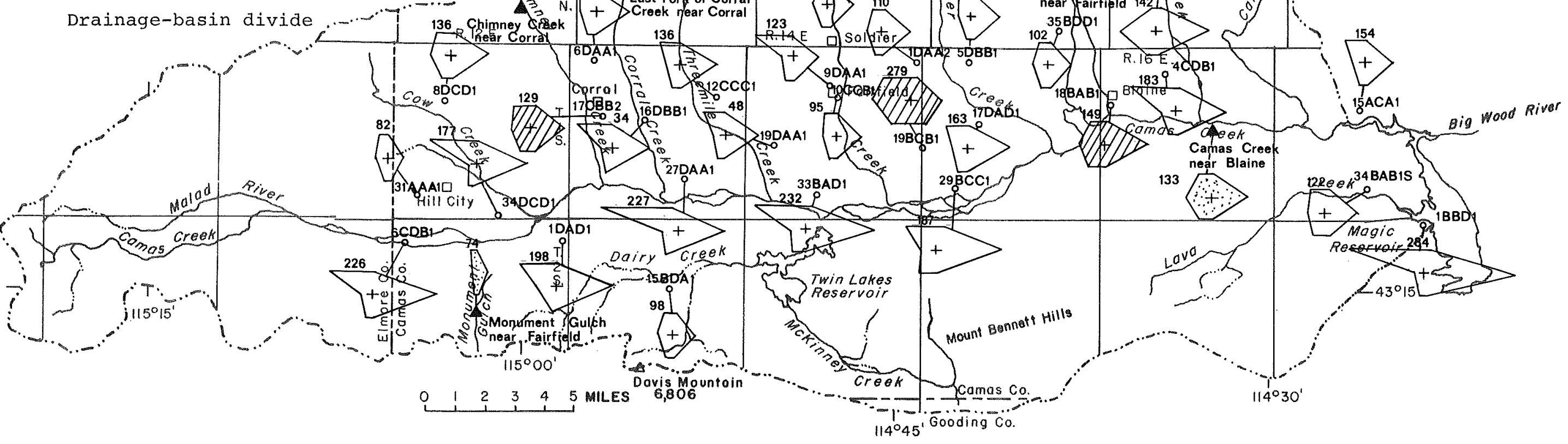

CHEMICAL CHARACTER OF WATER 
terns (opposite page) are shown in milliequivalents per liter. A milliequivalent per litex is one-thousandth of a unit chemical combining weight of a constituent in a liter of water. A milli- equivalent per liter is obtained by dividing the concentration of the constituent in milligrams per liter by the chemical combining weight of the constituent. 
5.0 WATER QUALITY (Continued)

5.2 Ground-Water Suitability for Use

\section{SOME CHEMICAL CONSTITUENTS EXCEED RECOMMENDED LIMITS}

Iron, manganese, nitrite plus nitrate (as nitrogen), and fluoride concentrations in ground water exceed recommended limits in some wells.

Concentrations of iron, manganese, nitrite plus nitrate (as nitrogen), and fluoride in some wells in the Camas Prairie basin exceeded the upper limits for public supplies of $300 \mu \mathrm{g} / \mathrm{L}, 50$ $\mu \mathrm{g} / \mathrm{L}, 10 \mathrm{mg} / \mathrm{I}$, and $2.2 \mathrm{mg} / \mathrm{L}$, respectively (National Academy of Sciences and National Academy of Engineering, 1974). Iron concentrations greater than $300 \mu \mathrm{g} / \mathrm{L}$ were found in samples from 9 wells, and manganese concentrations greater than 50 $\mu \mathrm{g} / \mathrm{L}$ were observed in water samples from 12 wells. Fluoride concentrations of
4.6 and $2.4 \mathrm{mg} / \mathrm{L}$ were found in water from wells 1S-13E27DAAl and 1S-14E-9DAAI, respectively. A nitrite plus nitrate (as nitrogen) concentration of $18 \mathrm{mg} / \mathrm{L}$ was found in water from well 1S15E-19BCB 1 .

Iron and manganese concentrations in excess of the recommended limits may result in objectionable taste and staining of porcelain fixtures and clothing. Excessive fluoride concentrations can lead to dental fluorosis. Excessive nitrogen may cause blood disorders in infants. 
6.0 DATA NEEDS

6.1 Suggestions for Monitoring

\section{DATA FOR RESOURCE MANAGEMENT}

To provide data for management of ground-water resources of Camas Prairie basin, it is suggested that water levels in 15 wells be measured monthly and water-quality samples be collected from 5 wells yearly.

To provide adequate data to insure orderly development and management of groundwater resources of Camas Prairie basin, it is suggested that 15 wells be included in a water-levelobservation network and 5 wells be included in a water-quality network. These networks would monitor waterlevel fluctuations and trends and water-quality changes in the artesian and water-table aquifers. The locations of the suggested monitoring sites are shown on the map (opposite page).

The suggested observation-well network includes nine wells in the artesian aquifer and six wells in the water-table aquifer. Water levels or artesian pressures in these wells should be measured monthly.
The suggested waterquality network includes three wells in the watertable aquifer and two wells in the artesian aquifer. Chemical constituents to be analyzed should include the common cations, anions, and nutrients. Samples for analysis should be collected in July or August during the irrigation season.

The major objectives of the monitoring network are to determine (1) the response of the ground-water systems (or aquifers) to stress, (2) the status of ground-water storage, and (3) the quality of the water for use. To accomplish these objectives, periodic measurements in observation wells and collection of water-quality samples from selected wells would be required. 
23AAB1 Observation well and number, artesian aquifer

- Observation well and number,

22BBB water-table aquifer

${ }_{17 \text { свв2 }} \phi$ Water-quality well and number Drainage-basin divide

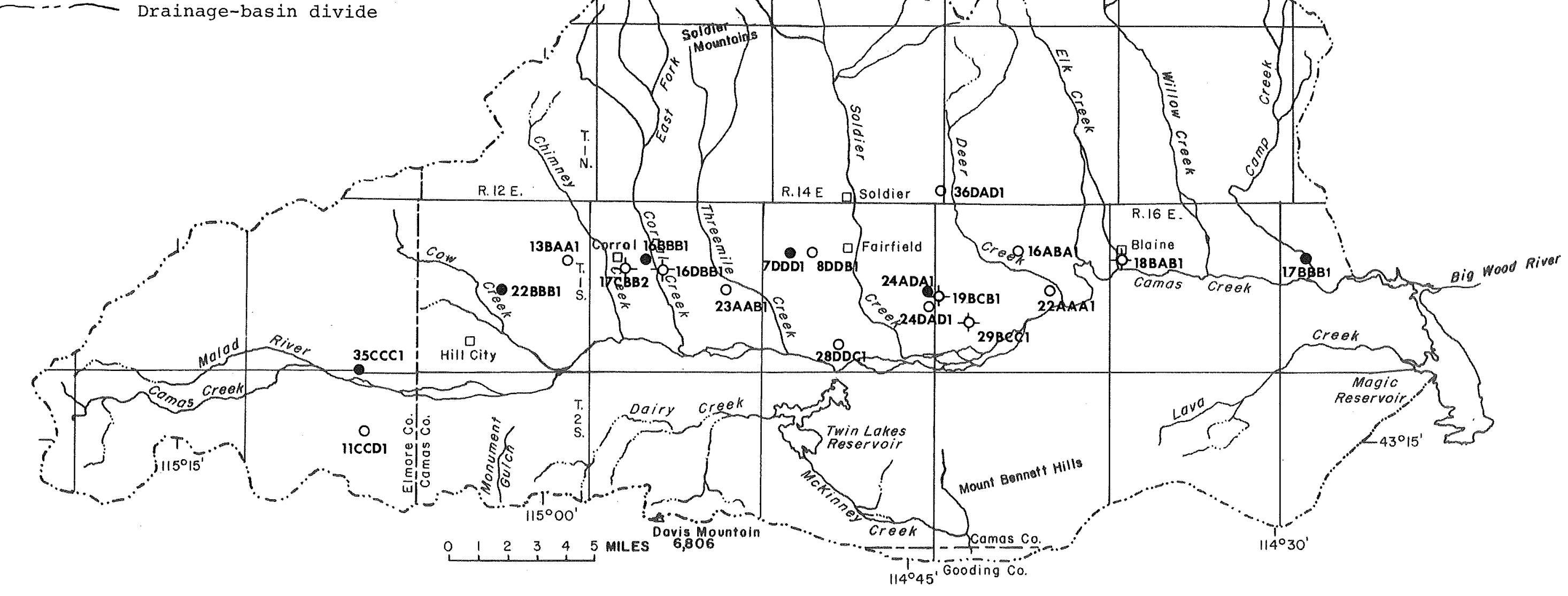

LOCATIONS OF SUGGESTED MONITORING SITES 
7.0 RESULTS

7.1 Summary

\section{GROUND-WATER LEVELS DECLINE IN RESPONSE TO INCREASED PUMPING FOR IRRIGATION}

Since 1974, pressure heads in the artesian aquifer have declined from 3 to $12 \mathrm{ft}$. Ground-water pumpage for irrigation and municipal supplies totaled nearly 9,500 acre-ft in 1977, compared to 1,350 acre-ft in 1957 .

Twenty-nine irrigation wells and two municipal wells pumped nearly 9,500 acre-ft of ground water in 1977, compared to 1,350 acre-ft in 1957 (Walton, 1962). Since 1974, pressure heads have declined from 3 to $12 \mathrm{ft}$ in the artesian aquifer. Pressure heads in the artesian aquifer drew down nearly 25 ft in response to 1977 (a arought year) pumping for irrigation. A comparison of measurements made in september 1957 and september 1977 show water-level declines of more than $30 \mathrm{ft}$ in places in the artesian aquifer.

Camas Prairie aquifers are recharged by percolation from streams and by precipitation falling on the valley floor. Estimated mean annual recharge to the artesian aquifer is 37,000 acre-ft, which agrees favorably with an earlier estimate (Walton, 1962) of 40,000 acre-ft. Vertical recharge from the artesian aquifer to the water-table aquifer is esti- mated to be 20,000 acreft annually (Walton, 1962). Declines in artesian pressure caused by increased irrigation pumping will result in a reduction of vertical recharge from the artesian aquifer to the overlying water-table aquifer.

Flows in Camas creek in the 1977 drought year averaged $13 \mathrm{ft}^{3} / \mathrm{s}(9,400$ acreft), compared to $191 \mathrm{ft}^{3} / \mathrm{s}$ $(138,000$ acre-ft) in a normal year.

Ground water occurs under artesian and watertable conditions in both sand and gravel of the valley-fill deposits and basalt of the Bruneau Formation. Yields from the valley-fill aquifer range from 400 to $1,200 \mathrm{gal} / \mathrm{min}$. Wells completed in the basalt aquifer generally have yields in a higher range, with some wells producing more than 2,000 gal/min. Water in the basin is of the sodium or calcium 
bicarbonate type with dissolved-solids concentrations ranging from 61 to $284 \mathrm{mg} / \mathrm{L}$. Concentrations of iron, manganese, nitrite plus nitrate (as nitrogen), and fluoride in water from several wells exceeded the upper limits recommended for public drinking-water supplies. To provide data for management of the groundwater resources of Camas Prairie, it is suggested that water levels in 15 wells be measured monthly, and water-quality samples from 5 wells be collected yearly. 


\subsection{SELECTED REFERENCES}

Malde, H. E., Powers, H. A., and Marshall, C. H., 1963, Reconnaissance geologic map of west-central snake River Plain, Idaho: U.S. Geological Survey Miscellaneous Geologic Investigations Map I-373, 1 sheet.

Moreland, Joe A., 1977, Ground water-surface water relations in the Silver Creek area, Blaine County, Idaho: Idaho Department of Water Resources, Water Information Bulletin no. $45,42 \mathrm{p}$.

National Academy of Sciences and National Academy of Engineering, 1974, Water-quality criteria, 1972: Washington, D.C., U.S. Government Printing Office, 594 p.

Riggs, H. C., 1969, Mean streamflow from discharge measurements: International Association Scientific Hydrology Bulletin, v. 14, no. 4, p. 95-110.

Ross, C. P., and Forrester, J. D., 1947, Geologic map of the State of Idaho: U.S. Geological Survey and Idaho Bureau of Mines and Geology, I map.

Stiff, H. A., Jr., 1951, The interpretation of chemical analysis by means of patterns: Journal of Petroleum Technology, v. 3, no. 10, p. 15-17.

Walton, W. C., 1962, Ground-water resources of Camas Prairie, Camas and Elmore Counties, Idaho: U.S. Geological Survey Water-Supply Paper 1609, $57 \mathrm{p}$.

Young, H. W., Harenberg, W. A., and Seitz, Harold R., 1977, Water resources of the Weiser River basin, west-central Idaho: Idaho Department of Water Resources, Water Information Bulletin no. 44, 104 p.

Young, H. W., and Mitchell, J. C., 1973, Geothermal investigations in Idaho, part 1, Geochemistry and geologic setting of selected thermal waters: Idaho Department of Water Resources, Water Information Bulletin no. 30, $43 \mathrm{p}$. 